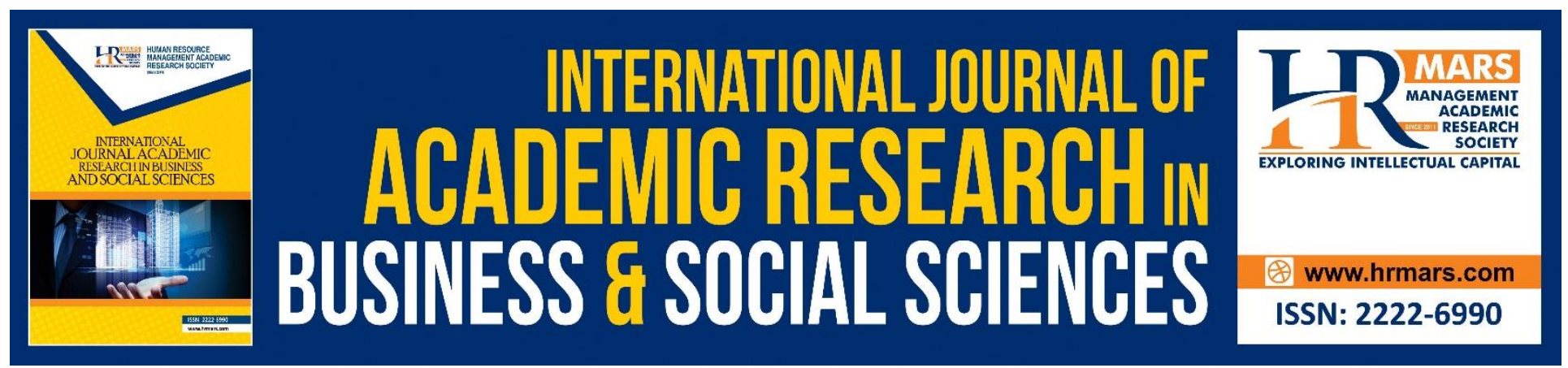

\title{
Evaluating the Economics Benefits of Space Science R\&D
}

\author{
Mhd Fairos Asillam, Mustafa Din Subari
}

To Link this Article: http://dx.doi.org/10.6007/IJARBSS/v9-i2/5640

DOI: $\quad 10.6007 /$ IJARBSS/v9-i2/5640

Received: 30 Jan 2019, Revised: 25 Feb 2019, Accepted: 02 March 2019

Published Online: 05 March 2019

In-Text Citation: (Asillam \& Subari, 2019)

To Cite this Article: Asillam, M. F., \& Subari, M. D. (2019). Evaluating the Economics Benefits of Space Science R\&D. International Journal of Academic Research in Business and Social Sciences, 9(2), 932-948.

\section{Copyright: (C) 2019 The Author(s)}

Published by Human Resource Management Academic Research Society (www.hrmars.com)

This article is published under the Creative Commons Attribution (CC BY 4.0) license. Anyone may reproduce, distribute, translate and create derivative works of this article (for both commercial and non-commercial purposes), subject to full attribution to the original publication and authors. The full terms of this license may be seen

at: $\underline{\text { http://creativecommons.org/licences/by/4.0/legalcode }}$

\section{Vol. 9, No. 2, 2019, Pg. 932 - 948}

Full Terms \& Conditions of access and use can be found at http://hrmars.com/index.php/pages/detail/publication-ethics 


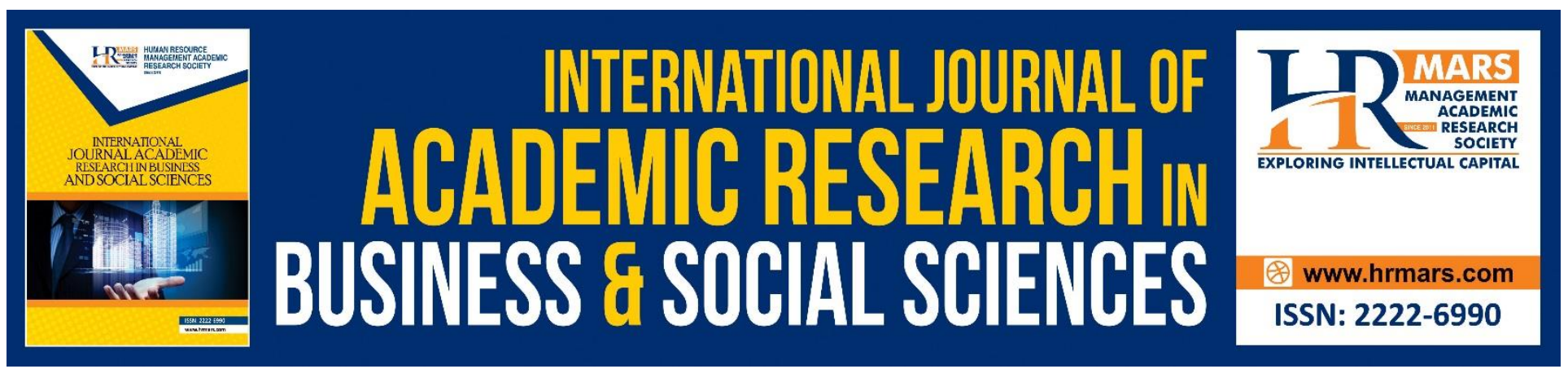

\title{
Evaluating the Economics Benefits of Space Science R\&D
}

\author{
Mhd Fairos Asillam, Mustafa Din Subari \\ Perdana School of Science, Technology \& Innovation Center, UTM, Malaysia
}

\begin{abstract}
Space science plays a role and brings impact to the society since the last 50 years and will keep providing return on investment to the country. Space technology is indeed a strategic sector with high potential of return (Subari \& Hassan, 2016) where developed countries reap benefits from it. Space science is important in space programme, in the form of new knowledge that provides solution to the world problem such as the understanding of Earth-Sun relationship to tackle global climate change. Other than that, space science provides economic opportunities besides protecting humans from massive destruction against asteroid impact of super solar flare. This paper outlines the benefits of space science research and development (R\&D) activities from the aspects of knowledge, economy, social or strategy while projecting future benefits.
\end{abstract}

Keywords: Space Science, R\&D, Economics

\section{INTRODUCTION}

Every year, the period between $4^{\text {th }}$ and $10^{\text {th }}$ October marks the World Space Week (WSW). On $4^{\text {th }}$ October last 60 years, Sputnik, the first Earth satellite was launched, followed by the launching of Explorer-1 by the US. This is the beginning of space technology era. In the meantime, the International Council on Space Research (COSPAR) was established in 1958 as the platform for scientists from different countries to discuss matters related to space research programs for the benefits of the mankind. With the cooperation of the United Nations Office for Outer Space Affairs (UNOOSA) and International Astronomical Union (IAU), the accomplishments and opportunities in space science have remarkably changed (Fisk, 2008).

Today, the world is very competitive, due to the limitation of resources. The government is accountable to justify each type of expenditures to the citizens. People would like to see the outcome from the programmes and activities organized by the government. Since the beginning of the space era, the same scenario applies in the space science R\&D activities. With the increase of applied and commercial research, the outcome is expected to be more tangible and takes shorter time.

Recently, there is a future concern in research because of purported changes in the nature of knowledge and due to increasing pressure on scientists to demonstrate social and economic benefits 
of their work (Calvert, 2006). Apart from profit-driven research (mainly applied research) to design better products, basic science is often neglected, even it is important in R\&D (Prettner \& Werner, 2016). In general, the policymakers are still wondering the economic benefits of conducting basic science R\&D. This scenario is worse in space science R\&D. Nevertheless, space science is still relevant even if its role is less significant in the next 50 years.

\section{DEFINITION AND SCOPE}

\section{Basic Science Research}

Basic science research focuses on "curiosity-oriented" and strategic research but the process or final product is still unclear (Ben Martin \& Salter, 1996). The primary objective is to acquire new knowledge in the name of science (Salter \& Martin, 2001). People gain knowledge from the outcome of the research. The discipline is known as epistemology, coming from two Greek words - 'episteme' that means knowledge and 'logos' that means a word or reason. Hence, epistemology means the reason behind the knowledge. Epistemologists study what makes up knowledge, the kinds of things that people know, the limits to what people know, and the possibility of knowing anything at all (Paul Pardi, 2011).

In the broadest sense, research is defined as the act of gathering data, information and facts for knowledge advancement (Martyn Shuttleworth, 2008). In general, research is a way of thinking and finding answers to the questions that arise. However, scientific research is a systematic way of gathering data to harness curiosity. It also provides scientific information and theories to provide explanation regarding the nature and the world. It renders practical applications possible (Armstrong \& Sperry, 1994).

The basic definition of science is "systematic knowledge of nature via repeatable observation and experimentation". It aims to discover the laws that govern natural phenomena (Matthias Tomczak's, 2008). Science is a way of knowing that requires a solid foundation (Wenning \& Specialist, 2009). Basic research science is conducted as one of the ways to produce knowledge. The capacity to produce and utilise knowledge is the key that contributes to the competitive edge of national economy (BĂTĂGAN, 2008). According to (BĂTăGAN, 2008), knowledge is a the main source of innovation, in which it is the subject of many studies in social science as depicted in Figure 1 . Figure 1 shows knowledge society that is attributed to new technology, research, innovation as well as learning. For a nation to progress better in technological revolution, the access to more knowledge and information is crucial (BĂTĂGAN, 2008). 


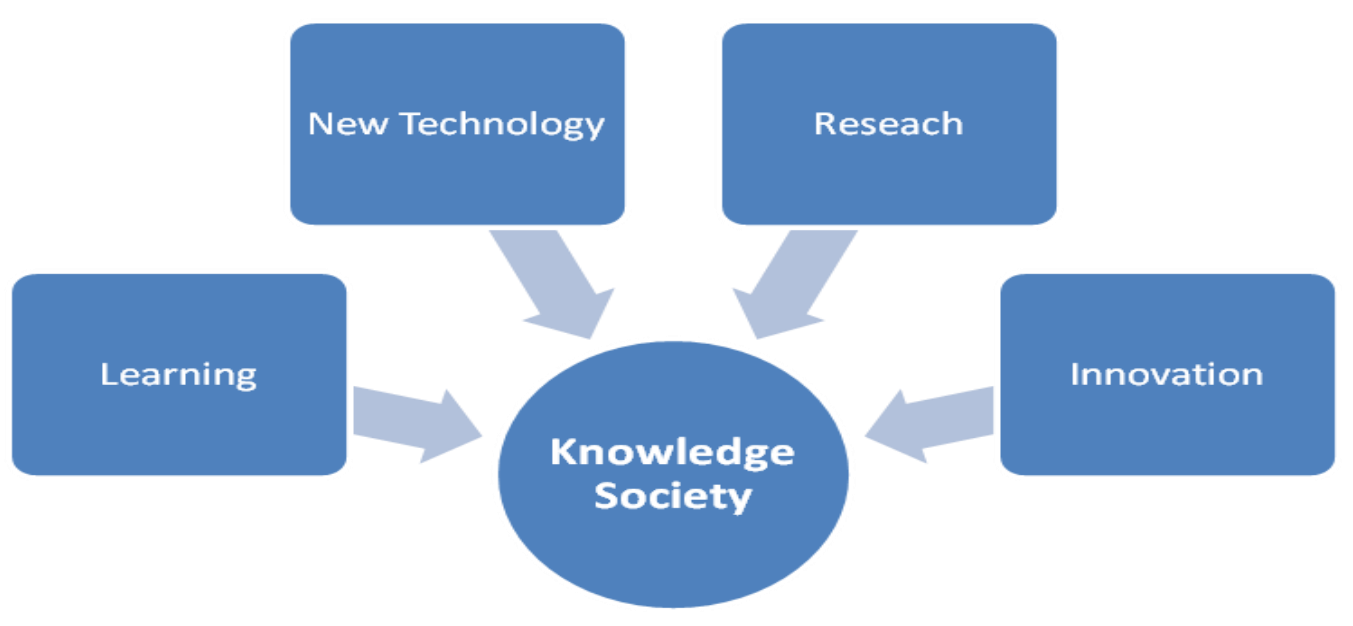

Figure 1: Knowledge society

(BĂTĂGAN, 2008) also mentions that investment in research is important to come up with knowledge dynamic and economic growth, as shown in Figure 2.

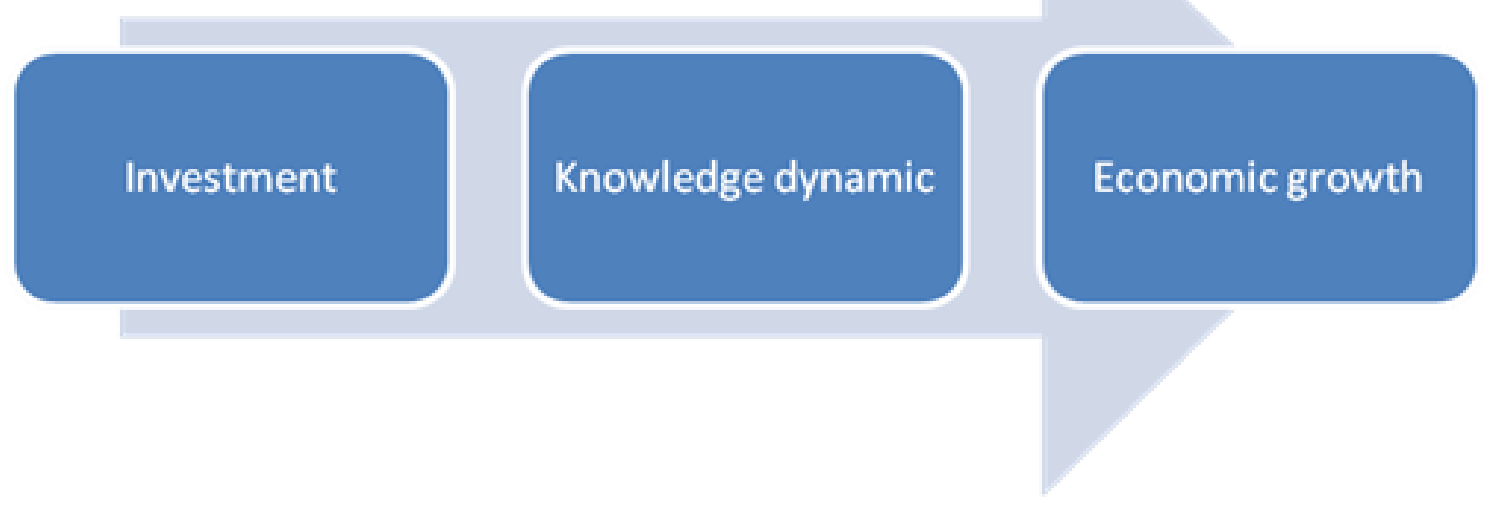

Figure 2: Investment in knowledge leads to knowledge dynamic and economic growth

\section{Space Science}

'Space' covers a range of terms, encompassing value proposition across the public, private and third sectors. This includes R\&D, engineering, manufacturing, operation, application, commercialisation, innovation, technology and knowledge transfer, diffusion, education and promotion in the areas of science, exploration, earth observation, communication, navigation, and defense (Sadlier, Flytkjær, Halterbeck, Varma, \& Pearce, 2015). However, this study focuses on space science R\&D. Space programmes take place at the edge of knowledge (Hof, Koopmans, Lieshout, \& Wokke, 2012). Space science includes but not limited to astrobiology, astronomy, climatology and atmosphere studies, 
comparative planetology, geodesy, human biology and medicine, materials research, meteorology, physics, and tectonics (Schwartz, 2014). In fact, space science provides support and contributes to the understanding of the universe. One of the ways to understand the universe is via space exploration mission, which provides the opportunities for scientists to gather valuable scientific data (Schwartz, 2014). However, the boundary between space science, space technology and space application activities is fuzzy. Using similar concept to differentiate basic science and applied science, the distinction between space science, space technology and space application should be scrutinised.

In general, they are three (3) reputable organisations that are recognised internationally on matters related to space governance. They are the United Nations Office for Outer Space Affairs (UNOOSA), International Astronomical Union (IAU) and Committee on Space Research (COSPAR). In this study, the definition of space science is adopted from UNOOSA. According to (COPOUS, 2014), space science ranges from astrophysics, human and robotic space exploration, and satellite-based communications, in which all these services are related to life science. Space science continues to be the fundamental part to enable several nations to utilise space technology and apply it for the benefit of the society. Space science help the mankind to advance their knowledge of the universe and carry out the roles to stimulate the development of new technology, applications and solutions. Hence, this enables people to address the challenges faced by the humanity and inspires people from all walks of life to be better. Space science is an ideal tool for capacity-building in science and technology worldwide. In fact, space science is split into six (6) main areas, as demonstrated in Figure 3.

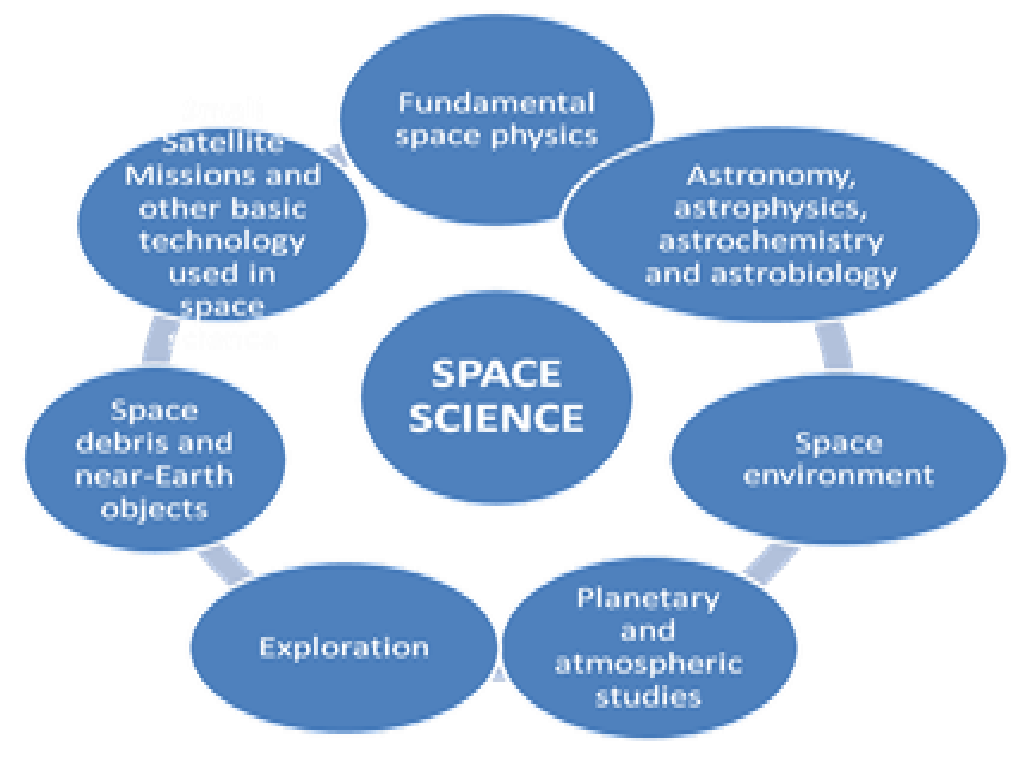

Figure 3: Six areas in space science according to UNCOPUS

\section{Economic}

Knowledge is dynamic in nature. There are various outputs as a result of knowledge activities, it can be economic, environmental, social or cultural aspect. However, this study focuses on economic benefits as an output from space science R\&D. There is blurred distinction between the economic 
INTERNATIONAL JOURNAL OF ACADEMIC RESEARCH IN BUSINESS AND SOCIAL SCIENCES

Vol. 9, No. 2, Feb, 2019, E-ISSN: 2222-6990 C 2019 HRMARS

and non-economic benefits. According to (Salter \& Martin, 2001), the definition of economic benefits can be referred to competencies, techniques, instruments, networks and the ability to solve complex problems.

\section{Strategic Sectors}

According to Reverso dictionary, strategic means the core aspect in something such as the military operation or political policy, especially when the areas have better progress than the others. Meanwhile, according to Cambridge dictionary, strategic industry is defined as the industry that is regarded to be important by the government for the country's economy or safety. There are many perspectives that determine which sectors are considered as strategic. Referring to bcg. perspective website, "A strategic sector is one in which you can obtain a competitive advantage and exploit it". Strategic sectors are defined in terms of competitive edge. To show to what extent space programme and space science R\&D can provide strategic return to a particular nation, a simple analysis that shows what "strategic" means is summarised in Table 1.

According to Table 1, space science is considered to be strategic in terms of capacity-building, multidiscipline (cross-border discipline), security, creation of new economy in the future, international cooperation, political, space diplomacy, new and emerging technologies, societal and environmental issues, solution for future problem and challenges, nation competitiveness and niche area development. Space is regarded as an important and strategic sector because it becomes a determining factor in many policies. It is an enabler to respond to societal challenges and it contributes to the smart and highly-qualified jobs, as well as competitiveness in the European economy. Therefore, space is a strategic sector that supports jobs and economic growth in Europe. It drives innovation and research, has significant influence on politics and affects the daily lives of all citizens (Chris, 2017). 
INTERNATIONAL JOURNAL OF ACADEMIC RESEARCH IN BUSINESS AND SOCIAL SCIENCES

Vol. 9, No. 2, Feb, 2019, E-ISSN: 222 2-6990 (C) 2019 HRMARS

Table 1: How "strategic" term is used in different perspectives

\begin{abstract}
Subject
Capacity-building, strategic key technologies and competitiveness

To ensure comprehensive exploitation of space, Germany must maintain its own system competencies, enjoy guaranteed access to strategic key technologies, and be capable to operate such systems and control the associated value chain. This requires the existence of a scientific, technical and industrial base in the country itself, not in the interest of autonomy of action. Long-term effect such as domestic competence serves to maintain competitiveness and sovereignty besides strengthening Germany's competitive edge relative to its partners in Europe and worldwide.
\end{abstract}

Multidiscipline (cross-border discipline)

Decisions or plans designed to affect the key factors for an outcome desired by an organisation, game, system, venture, or war.

\section{Security}

1. Dual-use technology;

2. Related to the gaining of overall or long-term military advantage of human/material resources; and

3. Protecting the Earth.

\section{New economy and social benefits}

1. An industry that is considered to be very important by a government for the country's economy or safety.

2. Industrial strategy is about the entire government working in partnership with industry to draft and deliver long-term plans to secure jobs and growth. Industrial strategy provides support to all economic sectors to increase global competitiveness, support innovation and maximise export potential.

3. Strategic industry is related to activities which trickles down to the whole country's economy, with forward and backward linkages in terms of material and knowledge input.

4. To be "strategic", an industry needs to provide social benefits not only by its valueadded magnitude. In fact, strategic industries are "good" industries for a nation to have, just like how a firm decides which businesses are attractive for the firm to be involved in.

\section{International cooperation/political/space diplomacy}

An instrument to achieve economic, scientific, political and social goals. Today, space science makes contribution by promoting research and development, education and innovation, economic growth, providing highly-qualified jobs, improving quality of life, protecting the Earth, ensuring security and defense besides stimulating international cooperation. According to the European Commission in the Europe 2020 communication, space activities provide humans with "the tools to address some of the key challenges worldwide".

Creating new and emerging technologies

HM Government, 2017

\section{Source}

HM Government, 2017

British dictionary

HM Government, 2017

Cambridge Dictionary, 2016

Ross, 2014

(OECD), 1991

(OECD), 1991

HM Government, 2017 
INTERNATIONAL JOURNAL OF ACADEMIC RESEARCH IN BUSINESS AND SOCIAL SCIENCES Vol. 9, No. 2, Feb, 2019, E-ISSN: $2222-6990$ ๑ 2019 HRMARS

\begin{tabular}{l|l|}
\hline Solution for future problems and challenges & Google Dictionary, 2017 \\
By identifying long-term or overall aims and interests and the means to achieve them. & \\
\hline $\begin{array}{l}\text { Increase nation competitiveness } \\
\text { A strategic sector is the sector that can obtain competitive advantage and exploit it. } \\
\text { Strategic sectors are defined in terms of competitive edge. }\end{array}$ & bcg.perspective, 2017 \\
\hline $\begin{array}{l}\text { Niche area development } \\
\text { By identifying possibilities and failure in the market, the area where a private enterprise } \\
\text { will not underinvest or invest to generate significant wealth for the nation. }\end{array}$ & (HM Government, 2017) \\
\hline
\end{tabular}

\section{CONCEPTUAL FRAMEWORK TO HARNESS BENEFITS FROM SPACE SCIENCE R\&D}

The framework in space science R\&D and the return that contributes to the nation's development is referred to some scholars (BĂTĂGAN, 2008; Frontier Economics, 2014; Metzger, 2016) and demonstrated in Figure 4.

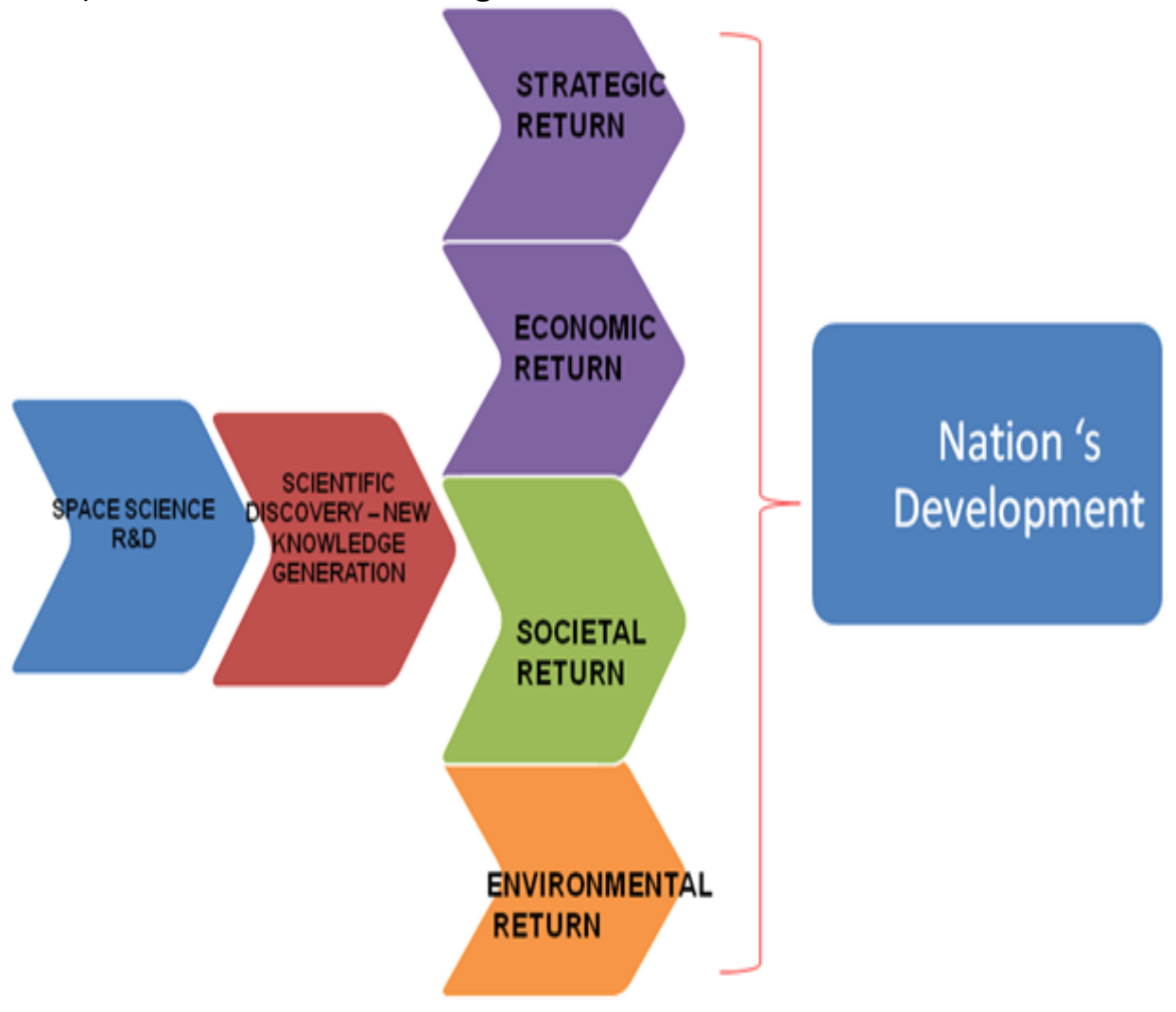

Figure 4: Conceptual framework

In general, the outcome from space science $R \& D$ is the new knowledge that can be categorised to four (4) sectors. Out of these four (4) sectors, this study focuses on strategic and economic returns 


\section{RESULT AND DISCUSSION}

After going through 18 journals (between 1995 and 2016) and 13 reports (between 1999 and 2017), the findings of the benefits of space science R\&D are depicted in Figure 5.

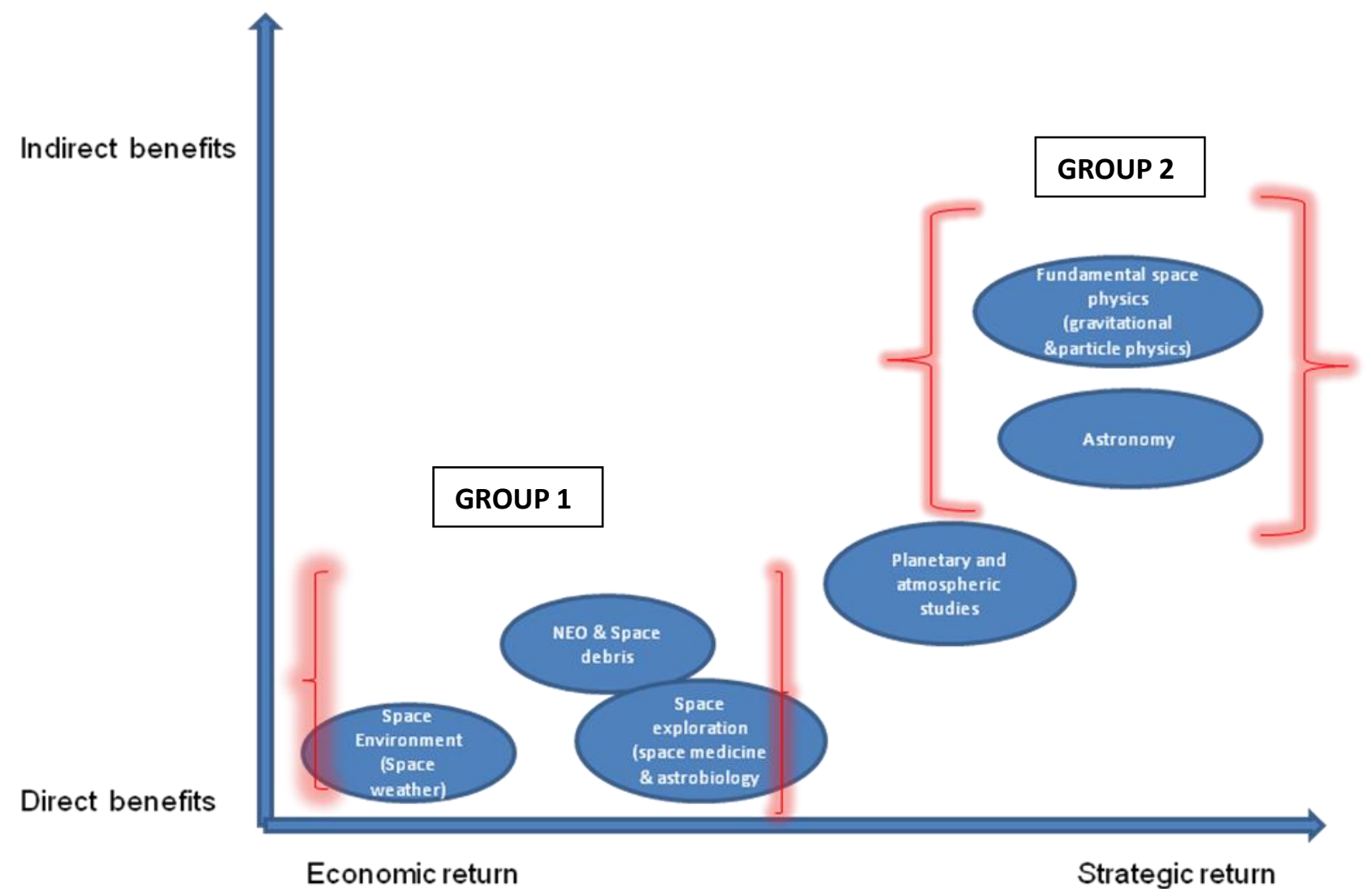

Figure 5: Initial findings from the evaluation of the ROI in space science R\&D

Using the UNOOSA's definition of space science illustrated in Figure 3, the six (6) areas of space science is mapped accordingly. There is a clear distinction in which the areas of space science is recategorised to two (2) groups namely group 1 and group 2. Group 1 is the areas with direct benefits in terms of economic return, where the return is immediate and instantly materialised. The most prominent area is the space environment, in which space weather is the subset of it. Space weather is a rapidly growing field which studies processes that take place between the Sun and the Earth (Innocenti et al., 2017). The development in space weather forecasting is so relevant to the society, where space weather does affect a number of technological assets, such as power and communication grids, transformers, pipelines and telecommunication infrastructure. According to (Hapgood \& Thomson, 2010), space weather risk management creates opportunity in business to save the latest technology. Therefore, the industry should look into consequence of any weather occurrences (Benfield, 2013). It is not easy to estimate the costs of such events, but (Benfield, 2013) did look into a report made by the US National Academy of Sciences in 2004. The cost of a repeat of the May 1921 event that involved magnetic field change in the US is estimated to be US\$ 2 trillion in 
INTERNATIONAL JOURNAL OF ACADEMIC RESEARCH IN BUSINESS AND SOCIAL SCIENCES

Vol. 9, No. 2, Feb, 2019, E-ISSN: 2222-6990 C 2019 HRMARS

the first four years, and the recovery process takes up to 10 years. Looking at Table 2, it is demonstrated that space weather does contribute to the economic benefits.

Table 2: Benefits of space weather activities

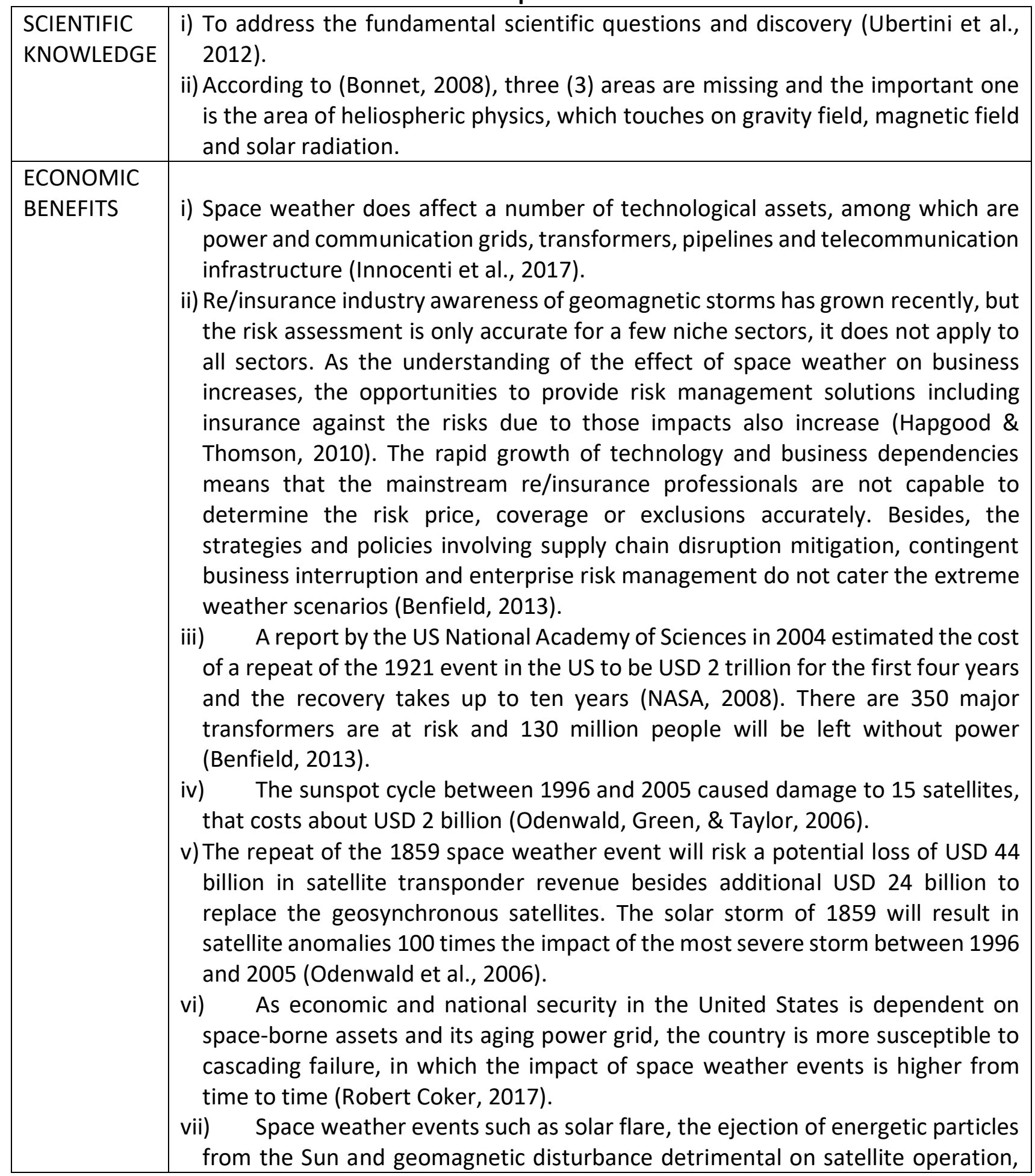




\begin{tabular}{|c|c|}
\hline & $\begin{array}{l}\text { the global positioning system (GPS), high-frequency (HF) airplane } \\
\text { communication, navigation, aviation, and electrical power grid. The disruption } \\
\text { has ripple effect even on the economic sectors that are not directly related to } \\
\text { space assets (e.g. financial services) to suffer from losses (Robert Coker, 2017). } \\
\text { viii) If the Carrington Event or the } 1921 \text { storm happened again, the damage is } \\
\text { estimated to be more than USD } 1 \text { trillion, and millions of people will be without } \\
\text { power and lose communications for months or years (Committee on the Societal } \\
\text { and Economic Impacts of Severe Space Weather Events:, 2015). } \\
\text { ix) In October 2003, a moderate coronal mass ejection (CME) forced astronauts } \\
\text { in the International Space Station (ISS) to take shelter from the increased } \\
\text { radiation, this led to diversion in polar route flights, GPS disturbance, Japanese } \\
\text { satellite failure, and induced power outage in Europe and Africa (Robert Coker, } \\
\text { 2017). } \\
\text { x) In January 2005, a minor space weather disrupted the HF radio communication } \\
\text { of transpolar airlines, resulting in rerouting of many flights and reduction in cargo } \\
\text { capacity (Hapgood \& Thomson, 2010). } \\
\text { xi) In November } 2015 \text {, a similar solar event affected radar stations in Sweden, } \\
\text { putting air traffic control off-line for an hour (Just, Press, \& Froberg, 2015) } \\
\text { xii) The strategic defence against space weather provides business } \\
\text { opportunities (Hapgood \& Thomson, 2010). } \\
\text { xiii) Space weather opens opportunities for new businesses (Hapgood \& } \\
\text { Thomson, 2010): } \\
\text { - The services to help other businesses mitigate space weather. } \\
\text { - The use of space weather information to improve the return from systems } \\
\text { affected by space weather. }\end{array}$ \\
\hline $\begin{array}{l}\text { STRATEGIC } \\
\text { BENEFITS }\end{array}$ & $\begin{array}{l}\text { i) Space weather affects human civilisation worldwide and this calls for a global } \\
\text { approach in research, monitoring, and forecasting (Head, 2015). } \\
\text { ii) Space weather is a natural issue for international cooperation and collaboration } \\
\text { (White House, 2010; European Commission, 2011). } \\
\text { iii) Space weather forecasting is prioritised to defend the main infrastructure } \\
\text { and human presence in space (Innocenti et al., 2017). } \\
\text { At the peak of the solar cycle } 23 \text { in March 2002, the time when Operation } \\
\text { Anaconda took place in Afghanistan, the ionospheric variability hampered UHF } \\
\text { communication, which resulted in an intense firefight that left seven Americans } \\
\text { dead (Kelly, Comberiate, Miller, \& Paxton, 2014). } \\
\text { v) In May 1967, a solar storm almost triggered nuclear war due to disruption of HF } \\
\text { communication across the polar cap (Knipp et al., 2016). This was at the height } \\
\text { of the Cold War, and the US interpreted the radio disruption as jamming by the } \\
\text { Soviet Union. }\end{array}$ \\
\hline
\end{tabular}




\begin{tabular}{|l|l|}
\hline FUTURE & i) Monitoring and forecasting issues: there is no extensive warning mechanism of \\
BENEFITS & $\begin{array}{l}\text { geomagnetic storms because the current forecasting system is insufficient } \\
\text { (Barbara Ferreira, 2010). } \\
\text { ii) Mitigation and resilience issues: More efforts are needed to educate service } \\
\text { providers that are vulnerable to space weather, as well as end-users (Barbara } \\
\text { Ferreira, 2010). }\end{array}$ \\
\hline
\end{tabular}

Group 2 is the areas with indirect benefits and categorised under strategic return. Indirect benefits mean that the society takes some time to experience the benefits. This is the area where the knowledge output from $R \& D$ requires more research to shift from the foundation to applied research, before entering into commercialisation research. It will take 15 to 20 years for the new knowledge to be converted to practical benefits. Astronomy is a unique and strategic area that provides information on Earth problems, whereas space science and exploration are vital to capture attention from the public especially the youths (Ocampo, Friedman, \& Logsdon, 1998). The benefits of astronomy activities are summarised in Table 3 while the benefits of astronomy and fundamental space physics are demonstrated in Table 4.

ASTRONOMY - Astronomy is the study of everything beyond Earth. It is a science driven by observations, with links to mathematics, physics, chemistry, computer science, geophysics, material science and biology (Monnet, Molster, \& Melnick, 2007).

Table 3: Benefits of astronomy activities

\begin{tabular}{|l|l|}
\hline $\begin{array}{l}\text { SCIENTIFIC } \\
\text { KNOWLEDGE }\end{array}$ & $\begin{array}{l}\text { To find answers regarding scientific questions and discovery (Ubertini et al., } \\
\text { 2012). }\end{array}$ \\
\hline $\begin{array}{l}\text { ECONOMIC } \\
\text { BENEFITS }\end{array}$ & $\begin{array}{l}\text { Technology-enabled innovation and cutting-edge scientific instrumentation } \\
\text { (Ubertini et al., 2012). } \\
\text { - The economic benefits that also drive technological advancement (Bode, } \\
\text { 2010). }\end{array}$ \\
\hline $\begin{array}{l}\text { STRATEGIC } \\
\text { BENEFITS }\end{array}$ & $\begin{array}{l}\text { Long term legacy in science (Ubertini et al., 2012). } \\
\text { - Astronomy is important for any society and culture and helps to encourage } \\
\text { the youths to be interested in physical science (Ubertini et al., 2012). } \\
\text { It is now possible to study objects which are far away when the universe was } \\
\text { stars and seek evidence of life over there (Bode, 2010). } \\
\text { The understanding of the atmosphere as the shield of Earth from space } \\
\text { radiations as well as space environment characterisation (Bode, 2010). }\end{array}$ \\
\hline $\begin{array}{l}\text { FUTURE } \\
\text { BENEFITS }\end{array}$ & $\begin{array}{l}\text { To gain understanding of the electromagnetic spectrum from radio to high } \\
\text { energy } x \text {-rays which contribute to strategic and economic benefits (Ubertini et } \\
\text { al., 2012). }\end{array}$ \\
\hline
\end{tabular}


INTERNATIONAL JOURNAL OF ACADEMIC RESEARCH IN BUSINESS AND SOCIAL SCIENCES Vol. 9, No. 2, Feb, 2019, E-ISSN: 2222-6990 C 2019 HRMARS

\section{Fundamental Space Physics - Particle physics}

Fundamental space physics is the study of the solar system natural phenomenon that revolves around the sun, the particles and the radiation it creates and how these affect the planets. Particle physics, which is known as high energy physics focuses on the nature of the particles that constitute matter and radiation. According to (Tuchming, 2018), particle physics is the study of building blocks of matter and radiation and their interaction. The fundamental particles are summarised by the standard model. This include leptons (such as electron), the quarks that make up protons and neutron, as well as gauge bosons that mediate force between the other particles.

\section{Table 4: Benefits of astronomy and fundamental space physics}

\begin{tabular}{|c|c|}
\hline $\begin{array}{l}\text { SCIENTIFIC } \\
\text { KNOWLEDGE }\end{array}$ & $\begin{array}{l}\text { New scientific knowledge (Schopper, 2016). } \\
\text { Although the main objective of basic research is the production of new } \\
\text { knowledge, in the long run it provides the basis for most of new technologies } \\
\text { (Schopper, 2016). }\end{array}$ \\
\hline $\begin{array}{l}\text { ECONOMIC } \\
\text { BENEFITS }\end{array}$ & Technological spillover/spin-off (Schopper, 2016). \\
\hline $\begin{array}{l}\text { STRATEGIC } \\
\text { BENEFITS }\end{array}$ & $\begin{array}{l}\text { - The European Organization for Nuclear Research (CERN) was founded with } \\
\text { the objectives to promote science and foster the understanding between } \\
\text { nations. The social evaluation of a project like the Large Hadron Collider (LHC) } \\
\text { cannot be completed without considering the aspect of 'science for peace'. The } \\
\text { appointment of CERN as an advisory organisation to the United Nations is a sign } \\
\text { of recognition of its achievements (Schopper, 2016). } \\
\text { - In a world where actions taken now affect more nations, CERN is looking for } \\
\text { the new ways to manage new challenges that create value to the society. Hence, } \\
\text { it is not surprising that the CERN model has been discussed many times in the } \\
\text { World Economic Forum (Schopper, 2016). } \\
\text { - The benefit of particle physics is the knowledge of the matter and the } \\
\text { development of the universe at its early stage (Schopper, 2016). }\end{array}$ \\
\hline $\begin{array}{l}\text { FUTURE } \\
\text { BENEFITS }\end{array}$ & $\begin{array}{l}\text { - Scientific progress and technical innovations are necessary for economic } \\
\text { growth (Schopper, 2016). } \\
\text { - } \quad \text { Discoveries in basic science have tremendous influence on the new } \\
\text { technologies thus make changes in the society (Schopper, 2016). } \\
\text { - Recently, CERN revealed that the electromagnetic force and the weak } \\
\text { nuclear force are the only two components of a more fundamental force, this } \\
\text { may have potential in technology for future generations (Schopper, 2016). } \\
\text { - From the experiments, the recent LHC Grid is shown to be more } \\
\text { powerful than the World Wide Web (WEB). However, its relevance for the } \\
\text { society is not yet determined (Schopper, 2016). }\end{array}$ \\
\hline
\end{tabular}

It is shown that astronomy and fundamental space physics provide new knowledge that will contribute to strategic benefits. 
Even the knowledge does not directly linked to economic return, the strategic benefits can benefit the mankind in different ways:

i) The space science and exploration over the years have captured the world's attention and interest. Most of the people are excited to discover and explore the solar system and look beyond the cosmos. This is the era to explore the new worlds besides of Earth that exist since the halfmillennium ago (Ocampo et al., 1998);

ii) This new age of discovery causes the humans to appreciate their habitat in the context of the solar system and the universe beyond (Ocampo et al., 1998);

iii) Basic science is the key to the nation's prosperity and it is impossible to expect economic and social development without a sound education and research in space science (Jasentuliyana, 1995);

iv) In the entire human history, people of all culture wonder about their place in the cosmos, the nature of the planets and stars and their relation to the Earth. Are they the only mankind? What is the effect of the evolution in the universe, stars, planets and themselves (Ocampo et al., 1998);

v) The search for life in the universe (via space exploration) requires multidisciplinary approaches, there is room for all. With widespread communication, instant data and information, and human interest especially the children in space discovery, space science and exploration now become worldwide activities (Ocampo et al., 1998);

vi) The benefits of space science and exploration (Ocampo et al., 1998); and

vii) Space science stimulates education and scientific literacy (Ocampo et al., 1998).

\section{CONCLUSION}

The world is now facing great challenges and space science R\&D offers solutions to combat global climate change, protect the Earth from the asteroids, open economic opportunities, advance the technical and science knowledge and improve the workforce technical competency (Fisk, 2008). The research mapping proves the relationship between space science R\&D and the nation's economic and strategic returns, now and in the future. Scientific progress and technical innovation are necessary for economic growth (Schopper, 2016). In fact, economic and strategic aspects are the two pillars in nation development.

This mapping provides reference to develop a framework or model to evaluate the relationship between space science R\&D with economic and strategic returns. The model will provide an outline for the development of the country's space science R\&D up to 2030. The objective is to prepare the country to advance itself in the space sector for the new economic development besides reinforcing the national strategic agenda. Space science R\&D is crucial if Malaysia aims to be advanced in the space technology and space application for the nation's socioeconomic development and to connect with the National Transformation 2050 (TN50). Space science R\&D is indeed the foundation to ensure the sustainability of the national space programme.

\section{FUTURE WORKS}

To improve the mapping outlined in this study, some recommendations are proposed to be conducted in the future:

i) The need to develop a dynamic model or framework to quantify the economic and strategic returns from the space science $R \& D$; and 
INTERNATIONAL JOURNAL OF ACADEMIC RESEARCH IN BUSINESS AND SOCIAL SCIENCES

Vol. 9, No. 2, Feb, 2019, E-ISSN: $2222-6990$ ๑ 2019 HRMARS

ii) The model will lead to a better policy framework for a fair (just) distribution of resources to drive the space programme to the nation's economic development.

\section{Corresponding Author}

Mhd Fairos bin Asillam,

Perdana School of Science, Technology \& Innovation Policy, Universiti Teknologi Malaysia, Malaysia Email: mhdfairos@gmail.com

\section{References}

(OECD), B. S. (1991). STRATEGIC INDUSTRIES IN A GLOBAL ECONOMY: Policy issues for the 1990s. In Support policies for stratgic industries: An assessement and some policy recommendations ( $p$. 97). Paris, France: OECD.

Armstrong, J. S., \& Sperry, T. (1994). The Ombudsman: Business School Prestige - Research Versus Teaching. Interfaces, 24(2), 13-43. https://doi.org/10.1287/inte.24.2.13

Barbara Ferreira. (2010). Space Weather. London, UK. https://doi.org/10.1029/gm125

BĂTĂGAN, L. (2008). Knowledge Dynamics and Economy Growth. Revista Informatica Economică, 4(4), 27-30.

Ben Martin, \& Salter, A. J. (1996). The Relationship Between Publicly Funded Basic Research and Economic Performance. Brighton, UK.

Benfield, A. (2013). Geomagnetic Storms. (Vol. 86).

Bode, M. (2010). A strategic plan for European astronomy: The ASTRONET infrastructure roadmap. In AIP Conference Proceedings (Vol. 1283, pp. 18-24). https://doi.org/10.1063/1.3506058

Bonnet, R.-M. (2008). Next 50 years of space research. Proceedings of the International Astronomical Union, 4(S257), 3-9. https://doi.org/10.1017/S1743921309029020

Calvert, J. (2006). What's Special about Basic Research ? Science, Technology, \& Human Values, 31(2), 199-220. https://doi.org/10.1177/0162243905283642

Chris, H. A. (2017). No Title.

Committee on the Societal and Economic Impacts of Severe Space Weather Events: (2015). Severe Space Weather Events - Understanding societal and economic impact. The National Academic Press (Vol. 1). https://doi.org/10.1017/CBO9781107415324.004

COPOUS, U. (2014). Report on the United Nations/Austria Symposium on Space Science and the United Nations (Graz, Austria, 22-24 September 2014). UNOOSA (Vol. A/AC.105/1).

Fisk, L. A. (2008). The impact of space on society: Past, present and future. Space Policy, 24(4), 175180. https://doi.org/10.1016/j.spacepol.2008.09.001

Frontier Economics. (2014). Rates of return to investment in science and innovation. Report for the Department for Business, Innovation and Skills.

Hapgood, M., \& Thomson, A. (2010). Space Weather: Its impact on Earth and implications for business. Space Weather The International Journal Of Research And Applications.

Head, J. N. (2015). Notes on a Vision for the Global Space Weather Enterprise. Advances in Space Research, 56(1), 106-110. https://doi.org/10.1016/j.asr.2015.04.003

HM Government. (2017). Building our Industrial Strategy. Green Paper. https://doi.org/https://www.gov.uk/government/uploads/system/uploads/attachment_data/f 
INTERNATIONAL JOURNAL OF ACADEMIC RESEARCH IN BUSINESS AND SOCIAL SCIENCES

Vol. 9, No. 2, Feb, 2019, E-ISSN: $2222-6990$ ๑ 2019 HRMARS

ile/586626/building-our-industrial-strategy-green-paper.pdf

Hof, B., Koopmans, C., Lieshout, R., \& Wokke, F. (2012). Design of a Methodology to Evaluate the Direct and Indirect Economic and Social Benefits of Public Investments in Space.

Innocenti, M. E., Johnson, A., Markidis, S., Amaya, J., Deca, J., Olshevsky, V., \& Lapenta, G. (2017). Progress towards physics-based space weather forecasting with exascale computing. Advances in Engineering Software, 111, 3-17. https://doi.org/10.1016/j.advengsoft.2016.06.011

Jasentuliyana, N. (1995). Viewpoint Basic space science and developing countries. Space Policy, 11(2), 89-94. https://doi.org/https://doi.org/10.1016/0265-9646(95)00003-U

Just, M., Press, T. A., \& Froberg, P. (2015). Solar storm knocks out flight control systems in Sweden. Physics Org, (November), 1-2.

Kelly, M. A., Comberiate, J. M., Miller, E. S., \& Paxton, L. J. (2014). Progress toward forecasting of space weather effects on UHF SATCOM after Operation Anaconda. Space Weather, 12(10), 601-611. https://doi.org/10.1002/2014SW001081

Knipp, D. J., Ramsay, A. C., Beard, E. D., Boright, A. L., Cade, W. B., Hewins, I. M., ... Smart, D. F. (2016). The May 1967 great storm and radio disruption event: Extreme space weather and extraordinary responses. Space Weather. https://doi.org/10.1002/2016SW001423

Shuttleworth, M. (2008). Definition of research. Retrieved August 1, 2017, from https://explorable.com/definition-of-research

Tomczaks, M. (2008). Science, Civillization and Society: A History of Interaction and Interdependence.

Metzger, P. T. (2016). Space development and space science together, an historic opportunity. Space Policy, 37, 77-91. https://doi.org/10.1016/j.spacepol.2016.08.004

Ocampo, A., Friedman, L., \& Logsdon, J. (1998). Why space science and exploration benefit everyone. Space Policy, 14(3), 137-143. https://doi.org/10.1016/S0265-9646(98)00012-5

Odenwald, S., Green, J., \& Taylor, W. (2006). Forecasting the impact of an 1859-calibre superstorm on satellite resources. Advances in Space Research, 38(2), 280-297. https://doi.org/10.1016/j.asr.2005.10.046

Paul Pardi. (2011). What is knowledge. Retrieved August 1, 2017, from http://www.philosophynews.com/post/2011/09/22/What-is-Knowledge.aspx

Prettner, K., \& Werner, K. (2016). Why it pays off to pay us well: The impact of basic research on economic growth and welfare. Research Policy, 45(5), 1075-1090. https://doi.org/10.1016/j.respol.2016.03.001

Coker, R. (2017). The trillion-dollar (solar) storm. The Space Review.

Ross, G. M. (2014). Industrial strategy: Government and Industry in Partnership - progress report. Royal United Services Institution. Journal (Vol. 71). https://doi.org/10.1080/03071842609421957

Sadlier, G., Flytkjær, R., Halterbeck, M., Varma, N., \& Pearce, W. (2015). Return from Public Space Investments An initial analysis of evidence on the returns from public space investments FINAL REPORT. Somerset House, New Wing, Strand, London WC2R 1LA, United Kingdom.

Salter, A. J., \& Martin, B. R. (2001). The Economic Benefits of Publicly Funded Basic Research: A Critical Review. Research Policy, 30(3)(March), 509-532.

Schopper, H. (2016). Some remarks concerning the cost/benefit analysis applied to LHC at CERN. 
Technological Forecasting and Social Change, 112, 54-64. https://doi.org/10.1016/j.techfore.2016.02.007

Schwartz, J. S. J. (2014). Prioritizing scientific exploration: A comparison of the ethical justifications for space development and for space science. Space Policy, 30(4), 202-208. https://doi.org/10.1016/j.spacepol.2014.08.010

Subari, M. D., \& Hassan, A. (2016). Developing the Space Industry of Malaysia : the Policy Frameworks. Journal of Science, Technology and Innovation Policy, 2(1), 18-22.

Tuchming, B. (2018). Long-sought decay of the Higgs boson seen. Nature.

Ubertini, P., Gehrels, N., Corbett, I., De Bernardis, P., MacHado, M., Griffin, M., ... Pavlinsky, M. (2012). Future of Space Astronomy: A global Road Map for the next decades. Advances in Space Research, 50(1), 1-55. https://doi.org/10.1016/j.asr.2012.03.009

Wenning, C. J., \& Specialist, P. E. (2009). Scientific epistemology : How scientists know what they know. J. Phys. Tchr. Educ. Online, 5(2), 3-15. 